\title{
Psychometric Development of Chemotherapy Side Effects Fear Scale
}

\author{
Ivana Vasić1, Slobodan Janković², Marija Jelić ${ }^{3}$ \\ ${ }^{1}$ Hospital Pharmacy Department, Clinical Centre Kragujevac, Kragujevac, Serbia \\ ${ }^{2}$ University of Kragujevac Faculty of Medical Sciences, Department of Pharmacology and Toxicology, Kragujevac, \\ Serbia \\ ${ }^{3}$ Hospital Pharmacy Department, Institute of Oncology and Radiology of Vojvodina, Sremska Kamenica, Serbia
}

\section{SUMMARY}

Anxiety, depression and fear in general are the most common emotional problems in people with cancer and it is necessary to recognize them. The patients' attitude towards the side effects of chemotherapy has changed significantly in recent years and psychological effects, rather than physiological ones, are becoming increasingly important.

The aim of this study was to develop and validate a reliable questionnaire that can measure cancer patients' fear of the chemotherapy side effects (CheSeFS).

A cross-sectional observational study involved 208 oncology and haematology patients at the Clinical Centre of Kragujevac, Serbia and the Institute for Oncology and Radiology of Vojvodina in Sremska Kamenica. The internal reliability of the questionnaire was estimated by calculating Cronbach's alpha coefficient, while the external reliability was calculated by the split-half method with approximately the same number of respondents. In order to test the construct validity of the CheSeFS, all participants filled out the Scale of Depression, Anxiety and Stress-21 (DASS-21) and the Short Subjective Well-being Scale (SSWS), validated in Serbian language.

Cronbach's $\alpha$ coefficient reveals strong internal consistency, with a value of 0.922 . The questionnaire demonstrated good structure and uniformity when randomly split into two parts. Exploratory component analysis revealed two factors with the same number of items that explain $61.691 \%$ of variance. The components are objective physiological effects of the treatment, and factor that depends on the patient's psychological and sociological status, with approximately the same percentage of variance. The CheSeFS was positively correlated with the DASS-21 scale $(\varrho=0.595, p=0.000)$.

CheSeFS is a unique, reliable and valid two-factor 14-item instrument, a clinically useful tool to assess fear of the chemotherapy side effects in cancer patients.

Key words: chemotherapy, side effects, fear, oncology, haematology

Corresponding author:

Ivana Vasić

E-mail: maxiva79@hotmail.com 


\section{INTRODUCTION}

Side effects of chemotherapy can vary greatly, depending on the properties of the drug being administered (pharmaceutical form, dosage, route of administration, interactions with other drugs). The most common side effects are nausea and vomiting, alopecia, chronic fatigue, skin and subcutaneous tissue damage, while less frequent are hepatotoxicity, neurotoxicity, cardiotoxicity, nephrotoxicity and reproductive toxicity. Individual characteristics of a patient, such as liver function, kidney function, comorbidities, age, and lifestyle habits like smoking and alcoholism, are all very important for the treatment outcome (1). The patient's attitude towards side effects of chemotherapy has changed significantly in recent years, and psychological effects (emotional, social, or effects on sexual function) rather than physiological ones, like hair loss, fatigue and malaise associated with anaemia, are becoming increasingly important to the patient (2). Timely information provided by professional staff and integration of patients into educational programs are amongst the most important psychosocial aspects of modern oncology (3).

Diagnosis of malignancy causes more intense emotional reactions than of any other disease. Confusion, anxiety and stress that follow the diagnosis and emotional problems such as depression or panic disorders in people with cancer can be quite serious and it is important to recognize them. An observational study published in 2009 in Australia pointed out that the prevalence of anxiety and depression was $45 \%$ and $25 \%$, respectively, and their role was as important as that of the general physiological factors, gastrointestinal problems, problems with nutrition and general body weakness (4). A cross-sectional study in Iran on one hundred-fifty patients with recent diagnosis of different cancers revealed that $29.3 \%$ patients had mild anxiety, $16.7 \%$ had symptomatic anxiety, yet mild and symptomatic depression were seen in $26.7 \%$ and $21.3 \%$ patients, respectively (5).

Several questionnaires, like BAI (Beck Anxiety Inventory), HAM-A (Hamilton Anxiety Rating Scale), SAS (Zung Self-Rating Anxiety Scale), DASS (Depression Anxiety Stress Scales), HADS (Hospital Anxiety and Depression Scale) among others, have been developed in order to evaluate components of fear such as anxiety and/or depression among patients. Fear is generally defined as individual's response to a potential threat or an actual event in order to protect life, compared to anxiety, which is not related to any specific object or phenomenon (6). Some patients will experience only certain types of fear, while others will experience the majority of them. Some questionnaires were developed to assess the level of fear of breast and colorectal cancer screening, fear of complete cancer treatment (chemo- and radiation therapy) and fear of cancer in general. To the best of our knowledge, an instrument or questionnaire that would assess the fear of chemotherapy side effects in cancer patients was yet to be developed.

The aim of this study was to develop an instrument that can assess the patients' fear of the side effects of the ongoing therapy, and then conduct a survey to test the reliability and validity of the instrument.

\section{MATERIALS AND METHODS}

\section{New questionnaire construction}

Construction of a questionnaire on fear of chemotherapy side effects has started with the review of relevant literature. Each of 22 items was constructed in the form of positive statement that should have reflected a certain element of fear. Five possible answers were offered for each statement, in the form of the Likert's scale: "not at all-never", "some of the timesometimes", "a good part of time-often", "most of time-almost always", and" all the time-always", rated from 1 ("not at all-never") to 5 ("all the time-always"). Two items were different than the others selected as a socially desirable, with offered answers YES or NO. The final version of CheSeFS was then reviewed by two internists - oncologists and a clinical pharmacist, employed at the Clinical Centre Kragujevac. Following confirmation of the validity for contention, clarity and comprehension, the final Serbian version of CheSeFS was copied and prepared for reliability testing. The final version of CheSeFS scale is shown in Appendix 1.

\section{Population and sample}

The final versions of the new questionnaire (CheSeFS), Scale of Depression, Anxiety and Stress-21 (DASS-21) and the Short Subjective Well-being Scale (SSWS), validated in Serbian language, were tested on patients waiting for chemotherapy. The survey took place in March, April and May 2016 at two state-owned 


\section{Appendix 1}

\section{Chemotherapy Side Effects Fear Scale (CheSeFS)}

Name:

Date:

Instructions. The following items describe possible reasons that could make you feel AFRAID of receiving chemotherapy treatment. Please review each item carefully and think about how afraid these statements make you feel. Please circle one answer per item to rate your fear of the chemotherapy side effects in relation to each statement.

1. I am afraid of losing appetite and the senses of taste and smell for a long time.
(1) Not at all-never.
(2) Some of the time-sometimes.
(3) A good part of time-often.
(4) Most of time-almost always.
(5) All the time-always.

2. I am afraid of losing my hair and wearing a wig.

(1) Not at all-never.

(2) Some of the time-sometimes.

(3) A good part of time-often.

(4) Most of time-almost always.

(5) All the time-always.

3. I am afraid of not being able to see my friends and spend time with them.

(1) Not at all-never.

(2) Some of the time-sometimes.

(3) A good part of time-often.

(4) Most of time-almost always.

(5) All the time-always.

4. I am afraid of severe pain during the therapy.

(1) Not at all-never.

(2) Some of the time-sometimes.

(3) A good part of time-often.

(4) Most of time-almost always.

(5) All the time-always.

5. I am afraid of rapid weight loss.

(1) Not at all-never.

(2) Some of the time-sometimes.

(3) A good part of time-often.

(4) Most of time-almost always.

(5) All the time-always.

6. I am afraid of having to take antidepressant drugs.

(1) Not at all-never.
(2) Some of the time-sometimes.

(3) A good part of time-often.

(4) Most of time-almost always.

(5) All the time-always.

7. I am afraid of mouth ulcers and sore throat.

(1) Not at all-never.

(2) Some of the time-sometimes.

(3) A good part of time-often.

(4) Most of time-almost always.

(5) All the time-always.

8. I am afraid of anaemia, nausea and fatigue.

(1) Not at all-never.

(2) Some of the time-sometimes.

(3) A good part of time-often.

(4) Most of time-almost always.

(5) All the time-always.

\section{I am afraid of permanent diarrhoea.}

(1) Not at all-never.

(2) Some of the time-sometimes.

(3) A good part of time-often.

(4) Most of time-almost always.

(5) All the time-always.

10. I am afraid of having to wait for treatment with other patients.

(1) Not at all-never.

(2) Some of the time-sometimes.

(3) A good part of time-often.

(4) Most of time-almost always.

(5) All the time-always.

11. I am afraid of having trouble sleeping and falling asleep.

(1) Not at all-never.

(2) Some of the time-sometimes.

(3) A good part of time-often. 
(4) Most of time-almost always.

(5) All the time-always.

12. I am afraid of persistent infections and compromised immune system.

(1) Not at all-never.

(2) Some of the time-sometimes.

(3) A good part of time-often.

(4) Most of time-almost always.

(5) All the time-always.

\section{I am afraid of lack of expert information when} needed.

(1) Not at all-never.

(2) Some of the time-sometimes.

(3) A good part of time-often.

(4) Most of time-almost always.

(5) All the time-always.

14. I am afraid of lasting side effects on my heart, lung, kidneys, etc.

(1) Not at all-never.

(2) Some of the time-sometimes.

(3) A good part of time-often.

(4) Most of time-almost always.

(5) All the time-always.

health care settings in Serbia: the Clinical Centre Kragujevac, Oncology and Radiology Centre, and the Institute of Oncology and Radiology of Vojvodina in Sremska Kamenica. The inclusion criteria were literacy and age over 18 . The exclusion criteria were pregnancy, lactation, cognitive disorders, mood disorders, mental retardation and incomplete patient files. The sample of patients was of consecutive nature, i.e. all oncology and haematology patients who visited hospital on the day of survey (and met inclusion and exclusion criteria) were offered the questionnaire. Basic personal and demographic data were acquired from all participants. The questionnaires were completed by the patients themselves. The study was approved by the Ethics Committee of the Clinical Centre Kragujevac, Serbia. The patients were treated with due respect and care, according to the principles stated in the Declaration of Helsinki.

\section{Reliability testing}

Reliability of the questionnaire was tested by four methods (7). First, internal consistency was determined through calculation of Cronbach's alpha for the whole questionnaire. Second, the questionnaire was divided by split-half method in two parts with the same number of items, and Cronbach's alpha for each of the parts was calculated. Using the alphas for both parts, number of items in each part and average correlation between items in both parts of the original questionnaire, the Spearman-Brown coefficient for the questionnaire as a whole was calculated by the Spearman-Brown "prediction" formula (8). Third, for each item the mean score and fourth, the item variances were calculated, in order to check their suitability for the measurement of the whole extent of fear.

\section{Factorial analysis}

Exploratory factorial analysis of the questionnaire was performed in order to discover principal factors. First, suitability of the questionnaire and the sample for factorial analysis was tested by KaiserMeyer-Olkin measure of sampling adequacy and by the Bartlett's test of sphericity. Then, the factors were extracted first without rotation, with a condition that eigenvalues had to be greater than 1.0, and using Screeplot (the extracted factors were above the "elbow" of the graph) (9). Second, reference axes were rotated orthogonally, using the Varimax method, and another extraction of the factors was made, using the same criteria as for the unrotated solution (10). Extracted factors were then named accordingly.

\section{Validity}

The content validity of the questionnaire was evaluated by an independent panel of three experienced clinicians at the Clinical Centre Kragujevac, Serbia: two internists - oncologists and a clinical pharmacist.

The construction validity was tested by two methods: 1) convergent validity testing by comparison of the CheSeFS score with the Scale of Depression, Anxiety and Stress-21 (DASS-21) score, and 2) divergent validity testing by comparison of the CheSeFS score with the score of the Short Subjective Well-being Scale (SSWS). The permission to use the Short Subjective Well-being Scale and Scale of Depression, Anxiety and Stress-21, previously validated in Serbian population, was granted by Assist. Prof. Veljko Jovanovic, psychologist, University of Novi Sad, Serbia $(11,12)$. The correlations between scores on the questionnaires were calculated. All 
calculations were performed by SPSS statistical software, version 20.0.

\section{RESULTS}

The first version of the CheSeFS questionnaire contained 22 items, which was, after the pilot and minor adjustments, tested on the sample of 208 patients: mean age $54.87+/-14.54$ years, male/female ratio $88 / 120(42.3 \% / 57.7 \%)$, years of formal education $12.01+/-2.858$, place of residence, urban/rural $=149 / 59$ $(71.6 \% / 28.4 \%)$, living alone/with partner $=51 / 157$ $(24.5 \% / 75.5 \%)$. The umber of respondents with cancer diagnosed for the first time was 154 (92.3\%). The number of patients receiving chemotherapy for the first time was 192 (74.0\%).

\section{Reliability testing}

After testing the original questionnaire and examining the results of the correlation matrix, mean values, variance, skewness and kurtosis of response distribution for each of the items, 8 items were removed, leaving the final version of the CheSeFS questionnaire with 14 items. Cronbach's alpha of the final version with 14 items was 0.922 . Mean values of responses, standard deviations, variance, skewness and kurtosis for each item are shown in Table 1. After division of the questionnaire by the split-half method, the Spearman-Brown coefficient for the questionnai- reas a whole was calculated by the Spearman-Brown "prediction" formula, with the resulting value of 0.927. Cronbach's alpha after division was 0.841 for the first part and 0.875 for the second part of the questionnaire.

\section{Factorial analysis}

Factorial analysis was performed using the principal components method. The Kaiser-MeyerOlkin measure of sampling adequacy was 0.867 and the Bartlett's test of sphericity was significant ( $\mathrm{p}=$ 0.000). Two factors were extracted after orthogonal rotation, explaining $61.691 \%$ of variance in total. The first factor bears 4.385 eigenvalues $(31,321 \%$ of variance), the second 4.252 (30,370\% of variance). The rotated component matrix is shown in Table 2 . Items $6,7,12,16,17,19$, and 24 belong to the first factor, which reflects objective physiological factors (dependent on the properties of the administered drug) affecting the fear of chemotherapy side effects. Items $10,11,13,20,21,22$, and 23 belong to the factor 2, which describes patient's emotional, psychological and sociological status affecting the fear of chemotherapy side effects.

\section{Validity}

The validity of convergent criterion was tested through non-parametric correlation between the score on the CheSeFS scale and the score on the Scale of

Table 1. Mean values, standard deviation, variance, skewness and kurtosis of Chemotherapy Side Effects Fear Scale responses to 14 items (the responses are rated from 1 to 5 on the Likert scale).

\begin{tabular}{l|c|c|c|c|c}
\hline \hline \multicolumn{1}{c|}{ Item } & Mean response & Standard deviation & Variance & Skewness & Kurtosis \\
\hline 6. & 1.86 & 1.146 & 1.313 & 1.337 & 0.836 \\
\hline 7. & 2.42 & 1.595 & 2.544 & 0.677 & -1.165 \\
\hline 10. & 1.76 & 1.076 & 1.158 & 1.658 & 2.193 \\
\hline 11. & 1.90 & 1.225 & 1.501 & 1.371 & 0.869 \\
\hline 12. & 1.93 & 1.208 & 1.459 & 1.336 & 0.829 \\
\hline 13. & 1.66 & 1.087 & 1.182 & 1.783 & 2.351 \\
\hline 16. & 1.64 & 0.962 & 0.925 & 2.014 & 4.292 \\
\hline 17. & 2.52 & 1.383 & 1.913 & 0.580 & -0.954 \\
\hline 19. & 1.92 & 1.203 & 1.447 & 1.268 & 0.614 \\
\hline 20. & 1.96 & 1.340 & 1.796 & 1.214 & 0.147 \\
\hline 21. & 2.35 & 1.350 & 1.823 & 0.719 & -0.680 \\
\hline 22. & 2.05 & 1.303 & 1.698 & 1.153 & 0.237 \\
\hline 23. & 2.08 & 1.396 & 1.948 & 1.111 & -0.085 \\
\hline \hline 2. & 2.37 & 1.334 & 1.780 & 0.738 & -0.630 \\
\hline \hline
\end{tabular}


Table 2. The rotated component matrix of the Chemotherapy Side Effects Fear Scale. Items within the shaded cells belong to the corresponding factor.

\begin{tabular}{l|c|c}
\hline \hline \multicolumn{1}{c|}{ Item } & $\begin{array}{c}\text { Factor 1 } \\
\text { (Physiological fear } \\
\text { component of } \\
\text { chemotherapy side } \\
\text { effects) }\end{array}$ & $\begin{array}{c}\text { Factor 2 (Subjective } \\
\text { fear component of } \\
\text { chemotherapy side } \\
\text { effects) }\end{array}$ \\
\hline $\begin{array}{l}\text { 6. I am afraid of losing appetite and the senses of taste } \\
\text { and smell for a long time. }\end{array}$ & 0.752 & 0.231 \\
\hline 7. I am afraid of losing my hair and wearing a wig. & 0.656 & 0.207 \\
\hline $\begin{array}{l}\text { 10. I am afraid of not being able to see my friends and } \\
\text { spend time with them. }\end{array}$ & 0.117 & 0.838 \\
\hline $\begin{array}{l}\text { 11. I am afraid of severe pain during the therapy. } \\
\text { 12. I am afraid of rapid weight loss. }\end{array}$ & 0.362 & 0.693 \\
\hline $\begin{array}{l}\text { 13. I am afraid of having to take antidepressant drugs. } \\
\text { 16. I am afraid of mouth ulcers and sore throat. }\end{array}$ & 0.767 & 0.128 \\
\hline $\begin{array}{l}\text { 17. I am afraid of anaemia, nausea and fatigue. } \\
\text { 19. I am afraid of permanent diarrhoea. }\end{array}$ & 0.635 & 0.520 \\
\hline $\begin{array}{l}\text { 20.I am afraid of having to wait for treatment with } \\
\text { other patients. }\end{array}$ & 0.5753 & 0.165 \\
\hline $\begin{array}{l}\text { 21. I am afraid of having trouble sleeping and falling } \\
\text { asleep. }\end{array}$ & 0.405 & 0.463 \\
\hline $\begin{array}{l}\text { 22. I am afraid of persistent infections and } \\
\text { compromised immune system. }\end{array}$ & 0.426 & 0.757 \\
\hline $\begin{array}{l}\text { 23. I am afraid of lack of expert information when } \\
\text { needed }\end{array}$ & 0.259 & 0.704 \\
\hline $\begin{array}{l}\text { 24. I am afraid of lasting side effects on my heart, } \\
\text { lung, kidneys, etc. }\end{array}$ & 0.756 & 0.7463 \\
\hline \hline
\end{tabular}

Table 3. Multi correlation matrix (non-parametric Spearman's coefficients at significant correlation $p=0.000)$ for convergent and divergent validity.

\begin{tabular}{l|c|c|c|c|c}
\hline \hline & DASS-A score & DASS-S score & $\begin{array}{c}\text { DASS-D } \\
\text { score }\end{array}$ & $\begin{array}{c}\text { DASS-21 } \\
\text { total score }\end{array}$ & SSWS score \\
\hline CheSeFS score & 0.572 & 0.572 & 0.536 & 0.595 & -0.038 \\
\hline \hline
\end{tabular}

Depression, Anxiety and Stress-21 (DASS-21). The validity of divergent criterion was tested through non-parametric correlation between scores on the CheSeFS scale and the Short Subjective Well-being Scale (SSWS) scale. Non-parametric correlation was chosen due to non-normal distribution of some of the scores. The CheSEFS was positively correlated with the DASS-21 scale $(\rho=0.595, p=0.000)$ and Spearman's correlation coefficients were the same for the DASS-A (part od DASS-21 scale measuring anxiety) and DASS-S (part od DASS-21 scale measuring stress) $\rho=0.572 ; p=0.000$, and Spearman's correlation coef- ficient was $\rho=0.536 ; \mathrm{p}=0.000$ for the DASS-D (part od DASS-21 scale measuring depression). The CheSeFS had negative and low correlation with SSWS scale $(\rho=-$ $0.038, p=0.000)$, explaining divergent validity. Spearman's correlation coefficients are shown in the Multi correlation matrix (Table 3).

Mean score of items explained by Factor 1 correlated well with the part of DASS-21 scale that measures anxiety $(\rho=0.603, p=0.000)$, while the mean score of items explained by Factor 2 correlated well with the part of DASS-21 scale that measures depression $(\rho=0.529, p=0.000)$. Population of patients who 
live alone, correlated much better with the part of DASS-21 scale that measures depression $(\rho=0.769, \mathrm{p}=$ $0.000)$ than those who live with a partner $(\rho=0.452$, $p$ $=0.000)$. Patients under 65 years of age correlated better with a DASS-21 scale in general $(\rho=0.685, p=$ 0.000 ) than the older ones ( $\rho=0.339, p=0.000)$. Comparison of mean score values for Factor 1 and Factor 2 reveals that the mean score of the first factor is higher (14.66 > 13.76).

\section{DISCUSSION}

The present study was designed to systematically develop an instrument that assesses fears of chemotherapy side effects, and also test the reliability and validity of this instrument. Final version of the CheSeFS scale with 14 items demonstrated satisfactory reliability and both divergent and convergent validity tests had good results. It is evident that the items related to the fear of nausea and vomiting and persistent allergies after chemotherapy were eliminated first, due to low values of mean, variance and correlation coefficient. This confirms the significant progress in the development and availability of supportive antiemetic therapy, although this is one of the most common side effects in cancer patients. Patients are much more likely to experience adverse reactions like nausea and vomiting compared to the period of thirty years ago (4). The low correlation to persistent allergies indicates that less toxic pharmaceutical forms of cytostatic drugs are available to patients, even in Serbian hospitals.

The first reaction of patients encountering a malignant disease is fear of death or fear of separation from the loved ones. Individual attitudes can vary, from complete indifference to panic disorder (13). It is essential to recognize, at the beginning of the chemotherapy application cycle, those patients with increased risk of mental instability since depression and anxiety lead to increased morbidity and mortality rates (10). Anxiety and stress are reactions to the most common serious adverse physiological effects of cytostatic therapy, especially during the progression and recurrence of the disease. This is consistent with the fact that depressive syndrome occurs in advanced cancer patients. The population of patients who live alone has a great representation of vulnerability in general. A lower level of fear in older population is explained by the presence of associated chronic diseases in these patients and being part of an already limited popu-lation compared to the younger ones.
Factorial analysis revealed two domains: physiological component of fear of chemotherapy side effects (Factor 1) and subjective (emotional, psychological and sociological) component of fear of chemotherapy side effects (Factor 2). The comparison indicates that patients show a higher level of fear for items found in the first domain since doctors and health care professionals assert them as serious. It is necessary for patients to read and be informed about them, because adequate information reduces anxiety and stress. However, the level of fear related to the consequences of chemotherapy that patients experience emotionally is very high. It is important to have a routine patient screening for the psychological symptoms before administering the next cycle, even when the need for such action is not immediately obvious. Patients need to describe their effect to the health care professionals involved in their treatment and management. Using reliable and valid assessment tools can help patients to verbalize and clarify their symptom experience into a more objective form, which can then be measured (14).

There are a few limitations that need to be considered in this study. It was not possible to perform retesting after 15-30 days and determine the temporal stability of the questionnaire, due to difficulties in separating and eliminating the patients who received the last cycle. The relatively short period of time was not sufficient for the adequate number of patients who come to receive chemotherapy for the first time. In some recent studies, there were significant relationships between anxiety and depression and the type of cancer and type of treatment, thus further research in this direction should be carried out, according to the chemotherapy cycles given (5). Due to the increasing number of cancer patients, insufficient number of doctors and nurses, as well as the lack of certain drugs, long waiting lists in our country, the reliability of this questionnaire should be examined in other countries, with the higher level of healthcare services. Health care professionals need to receive initial training and supervision in all stages of the screening procedure, so the cost-effectiveness of screening and support interventions need to be examined in future studies (15).

\section{CONCLUSION}

Fear can be a major impediment to the applica- 
tion of necessary healthcare measures, and it is important that reliable and valid assessment tools are available to measure its cause and extent. Chemotherapy Side Effects Fear Scale (CheSeFS) is a reliable and valid, clinically useful tool that measures the level of patients' fear of the chemotherapy side effects. The results of this study have further implications. Psychosocial screening with feedback and information of available services should be provided by healthcare professionals in routine oncology care. Identified patients must be provided with adequate psychotherapy and expert consultations in order to be successfully treated during the therapy. Special attention should be paid to the patients under 65 years of age, as well as the group of patients living alone, without the support of a life partner or family. After this first step, a lot of comprehensive effort is needed to increase the quality of life in cancer patients.

\section{DISCLOSURE}

The authors declare that no competing financial interests or conflict of interests exist. The funders had no role in the study design, data collection and analysis, and the decision to publish the paper.

\section{ACKNOWLEDGEMENTS}

The authors are grateful to Vlainka Samardzić, professional nurse - medical technician at the Haematology Clinic, Clinical Centre Kragujevac, for her assistance in data collection. The authors would also like to thank Assist. Prof. Veljko Jovanović, University of Novi Sad, for his permission to use the Short Subjective Well-being Scale and the Scale of Depression, Anxiety and Stress-21, validated in Serbian, to test construct validity of the instrument; and Petar Zivanić, a professional translator, for his assistance in producing the final language of this paper.

\section{References}

1. Fernandez Ortega P, Caloto MT, Chirveches E et al. Chemotherapy-induced nausea and vomiting in clinical practice: impact on patients' quality of life. Suppor CareCancer 2012; 20:3141-8.

https://doi.org/10.1007/s00520-012-1448-1

2. Carelle N, Piotto E, Bellanger A et al. Changing patient perceptions of the side effects of cancer chemotherapy. Cancer 2002; 95:155-63.

https://doi.org/10.1002/cncr.10630

3. Garcia S. The effects of education on anxiety levels in patients receiving chemotherapy for the first time: an integrative review. Clin J Oncol Nurs 2014;18:516-21.

https://doi.org/10.1188/14.CJON.18-05AP

4. Breen SJ, Baravelli CM, Schofield PE et al. Is symptom burden a predictor of anxiety and depression in patients with cancer about to commence chemotherapy? Med J Aust 2009;190:99-104.
5. Nikbakhsh N, Moudi S, Abbasian S, Khafri S. Prevalence of depression and anxiety among cancer patients. Caspian J Intern Med 2014; 5:167170.

6. Bay EJ, Algase DL. Fear and anxiety: a simultaneous concept analysis. Nurse Diagn 1999; 10:103-11.

https://doi.org/10.1111/j.1744-618X.1999.tb00036.x

7. Fajgelj S. Psychometry. Center for Applied Psychology,Beograd, 2005.

8. Janković S. Design Research Methods. Serbian Society for Rational Therapy in Medicine (MEDRAT), Kragujevac, 2016.

9. DeVellis RF. Scale Development: Theory and Applications (Applied Social Research Methods), 3.rd edition, SAGE Publications, Inc, 2011.

10. Young AG, Pearce S. A Begginer's Guide to Factor Analysis: Focusing on Exploratory Factor 
Analysis. Tutor Quant Methods for Psychol 2013; 9:79-94.

https://doi.org/10.20982/tqmp.09.2.p079

11. Jovanović V, Gavrilov-Jerković V, Žuljević D, Brdarić D. Psychometric evaluation of the Depression Anxiety Stress Scales-21 (DASS-21) in a Serbian student sample. Psihologija 2014; 47:93112.

https://doi.org/10.2298/PSI1401093I

12. Jovanovic V. Validation of the Short Subjective Well-being Scale (Serbian). Primenjena psihologija 2010; 3:175-90.
13. Gregurek R, Bras M, Djordjevic Vet al. Psychological problems of patients with cancer. Psychiatr Danub 2010; 22:227-30.

14. Brown V, Sitzia J, Richardson Aet al. The development of the Chemotherapy Symptom Assessment Scale (C-SAS): a scale for the routine clinical assessment of the symptom experiences of patients receiving cytotoxic chemotherapy. Inter J NursStud 2001; 38:497-510. https://doi.org/10.1016/S0020-7489(00)00106-1

15. Thalén-Lindström A. Screening and Assessment of Distress, Anxiety, and Depression in Cancer Patients. Acta Universitatis Upsaliensis 2014; 75. 


\title{
Izrada i ispitivanje pouzdanosti i validnosti upitnika za procenu nivoa straha bolesnika od neželjenih dejstava hemoterapije
}

\author{
Ivana Vasić1, Slobodan Janković2 ${ }^{2}$ Marija Jelić \\ ${ }^{1}$ Služba za farmaceutsku zdravstvenu delatnost, Klinički centar Kragujevac, Kragujevac, Srbija \\ ${ }^{2}$ Univerzitet u Kragujevcu, Fakultet medicinskih nauka, Departman za farmakologiju i toksikologiju, \\ Kragujevac, Srbija \\ ${ }^{3}$ Služba za farmaceutsku zdravstvenu delatnost, Institut za onkologiju i radiologiju Vojvodine, Sremska \\ Kamenica, Srbija
}

\section{SAŽETAK}

Anksioznost, depresija i strah su najčešći emocionalni problemi kod bolesnika obolelih od karcinoma i bitno ih je na vreme prepoznati. Stavovi bolesnika o neželjenim dejstvima hemoterapije se značajno menjaju poslednjih godina i sve bitniji su psihološki u odnosu na fiziološke efekte same terapije.

Cilj ovog rada bio je da razvije i testira validiran i pouzdan upitnik koji bi sveobuhvatno merio strah bolesnika sa karcinomom od neželjenih dejstava hemoterapije.

Sprovedena je opservaciona studija preseka bazirana na izradi, proveri pouzdanosti i validaciji Upitnika za procenu nivoa straha bolesnika od neželjenih dejstava hemoterapije (USNDH) kod ukupno 208 onkoloških i hematoloških bolesnika u Kliničkom centru Kragujevac i Institutu za onkologiju i radiologiju Vojvodine u Sremskoj Kamenici. Unutrašnja pouzdanost upitnika je procenjena izračunavanjem Kronbahovog koeficijenta (Cronbach 'salpha) za upitnik u celini, dok je eksterna pouzdanost izračunata SplitHalfmetodom sa približno istim brojem ispitanika. U cilju konvergentne validacije korišćena je Skala depresivnosti, anksioznosti i stresa-21 (DASS-21), dok je za diskriminantnu validaciju korišćena Kratka skala subjektivnog blagostanja (KSB) na srpskom jeziku.

Kronbahov koeficijent nakon eliminacije određenog broja pitanja iznosio je 0,922. Upitnik je pokazao dobru konstrukciju i homogenost pitanja prilikom nasumičnog deljenja upitnika na dva dela. Eksplorativna faktorska analiza je ukazala na postojanje dva faktora sa jednakim brojem pitanja koja objašnjavaju $61,691 \%$ varijansi $i$ to strah od fizioloških efekata same terapije i strah u zavisnosti od psihološko-sociološkoemocionalnog statusa bolesnika, sa približno jednakim procentom varijanse. Na osnovu pozitivnog koeficijenta korelacije krajnje verzije upitnika i skale DASS-21 $(\varrho=0,595, p=0,000)$, dokazana je konvergentna validnost konstrukcije.

USNDH je jednostavan, pouzdan i validan dvofaktorski instrument od 14 pitanja čijom kliničkom upotrebom je moguće identifikovati bolesnike sa povišenim nivoom straha, neposredno pre primene novog ciklusa hemoterapije.

Ključne reči: hemoterapija, neželjeno dejstvo, strah, onkologija, hematologija 